Jakub Gustaw Gajda

\title{
Republika islamska jako współczesna forma ustroju na przykładzie Iranu i Afganistanu
}

\author{
Specyfika kultury politycznej a proces kształtowania systemu
}

Republika islamska (IR), zwana również muzułmańską, jest formą ustroju opartego na prawie szariatu obowiązującą w czterech spośród zdominowanych przez wyznawców islamu państwach na świecie ${ }^{1}$. Według zachodnich norm, wywodzących się z oświeceniowego rozdziału kościoła od państwa ${ }^{2}$, republika islamska jako ustrój zawierający komponent religijny wpisuje się w definicję teokracji ${ }^{3}$. Tymczasem w percepcji uczonych oraz polityków świata islamu, forma ta jest interpretowana jako swoisty kompromis pomiędzy zachodnią demokracją liberalną a zgodnym z literą Koranu sprawowaniem władzy w państwie, stąd bywa określana terminem „islamskiej demokracji”. Republikę islamską uznać można ponadto za formę zamanifestowania niekolonialnego charakteru ustroju państwa, w wypadku państw, które przyjęły ten ustrój, a wcześniej bądź doświadczyły kolonialnego jarzma lub były tym jarzmem zagrożone. W tym kontekście republika islamska nie powiela w całości zachodnich wzorców demokratycznych, lecz obiera własną drogę zgodną z religią i kulturową tożsamością. W praktyce rola religii $\mathrm{w}$ republice islamskiej może być bardzo różna i niekiedy nad wyraz swobodnie określona. Stąd też, oprócz formalnej nazwy „republika islamska” odnoszącej się do nadrzędnej roli islamu w rzeczywistości politycznej i społecznej, niewiele łączy ze sobą państwa, które proklamowały tę formę ustroju. Podobnie też nie wszystkie z nich można posądzać o pozostawanie teokracją czy hierokracją. Dla zilustrowania tej tezy w niniejszym opracowaniu zostaną krótko scharakteryzowane i zestawione ze sobą dwie spośród współczesnych republik islamskich - sąsiadujące ze sobą: Islamska Republika Afganistanu oraz Islamska Republika Iranu.

\section{Geneza przyjęcia ustroju republiki islamskiej przez Iran}

Jak wspomniano we wstępie, obecnie na świecie istnieją cztery państwa, które przyjęły ustrój republiki islamskiej. Chronologicznie pierwszym z nich był Pakistan, który przyjął tę formę oficjalnie 23 marca 1956 r. Drugą najstarszą

${ }^{1}$ Pakistan, Mauretania, Iran i Afganistan.

${ }^{2}$ Termin „kościół” odnosi się w tym przypadku do religii, zresztą w Iranie i Afganistanie w tym kontekście mówi się właśnie o „oddzieleniu religii od polityki” (per. dżedaji-je din az sijasat).

${ }^{3}$ Teokracja [gr. theós 'bóg', krátos 'władza'] jest formą rządów, w której władzę w państwie sprawują kapłani bądź osoby głoszące, że znają wolę boga (bogów); wg Stownika języka polskiego pod red. W. Doroszewskiego „teokracja” to: 1. „forma rządów, w której najwyższą władzę państwową sprawują kapłani”, 2. „państwo rządzone w taki sposób”. 
istniejącą republiką islamską jest zachodnioafrykańska Mauretania, która określiła formę ustroju 28 listopada 1960 r. Iran i Afganistan pozostają więc najmłodszymi spośród istniejących republik islamskich ${ }^{4}$, a podkreślić należy, że w swej genezie historycznej dzieli je niemal ćwierć wieku. Iran został proklamowany jako republika islamska 1 kwietnia 1979 r. w wyniku antymonarchistycznej rewolucji i referendum, przeprowadzonego 10 i 11 farwardina 1358 r. hidżry słonecznej (30 i 31 marca 1979 r.), w którym za zniesieniem monarchii i wprowadzeniem islamskiej republiki opowiedziało się aż 98,2 proc. głosujących ${ }^{5}$.

Co istotne, w antyszachowskiej rewolucji irańskiej z 1979 r., która za główny cel obrała odsunięcie monarchy od władzy, brało udział wiele grup politycznych o szerokim wachlarzu światopoglądowym (od marksizmu po nacjonalizm $)^{6}$ i dopiero wybór republiki islamskiej jako nowej formy ustroju de facto dookreślił charakter samej rewolucji irańskiej, czyniąc ją właśnie islamską. Późniejsze represje podejmowane przez nowe władze wobec grup o proweniencji komunistycznej, ateistycznej i związanych z wszelkimi innymi ideologiami uznawanymi za sprzeczne $\mathrm{z}$ islamem ${ }^{7}$, ugruntowały nową formę irańskiego ustroju nadając jej, głównie zagranicą, ale także w wielu środowiskach w samym Iranie, etykietę reżimu fanatycznego, nietolerancyjnego i represyjnego. Iran stał się w opinii Zachodu sztandarowym przykładem współczesnej teokracji ${ }^{8}$.

W tym miejscu należy wrócić do początku rewolucji i podkreślić, że różne mogły zaistnieć formy ustroju po zniesieniu monarchii w Iranie, gdyby nie charyzmatyczne przywództwo ajatollaha Ruhollaha Chomejniego. Wśród możliwych opcji wskazuje się dziś najczęściej na demokratyczną republikę islamską, republikę ludową oraz republikę demokratyczną9. To jednak charyzma Chomejniego okazała się czynnikiem decydującym, który doprowadził do przyjęcia przez Irańczyków jego koncepcji państwa - republiki islamskiej z naczelną rolą autorytetu religijnego - welajat-e faqih (velāyat-e faqih) ${ }^{10}$. Jakkolwiek Chomejni czerpał również z myśli innych irańskich myślicieli politycznych, takich, jak: Dżalal Al-e Ahmad (1923-1969) czy Ali Szariati (1933-1977) - których również uznaje się za ideologów rewolucji islamskiej, to niewątpliwie, inspirowana myślą platońską króla-filozofa ${ }^{11}$, koncepcja nadrzędnej władzy

\footnotetext{
${ }^{4}$ Republikami Islamskimi były także Turkiestan Wschodni (1933-1934) i Gambia (2015-2017).

${ }^{5}$ D. Hiro, Holy Wars: The Rise of Islamic Fundamentalism, London 2013, s. 169.

${ }^{6}$ B. Baktiari, Parliamentary Politics in Revolutionary Iran: The Institutionalization of Factional Politics, Gainesville 1996, s. 55.

${ }^{7}$ M. Moojan, An Introduction to Shi'i Islam, London 1985, s. 297.

${ }^{8}$ Zob. L. Perl, Political Systems of the World: Theocracy, New York 2008, s. 15-43.

${ }^{9}$ P. Paydar, Women and the Political Process in Twentieth-Century Iran, London 1995. s. 226.

${ }^{10}$ Idea velayat-e faqih, która została implementowana w Iranie po rewolucji 1979 r. została opisana przez ajatollaha Chomejniego w roku $1970 \mathrm{w}$ książce o tym samym tytule (R. Chomejni, Velajat-e faqih: hokumat-e Eslami, Bejrut 1349 [1970]).

${ }^{11}$ Zob. Platon, Państwo (przekład W. Witwicki), ks. V, Kęty 2003, s. 149-198.
} 
autorytetu w zakresie prawa muzułmańskiego i Koranu, była jego koncepcją. Tę koncepcję udało mu się osobiście w Iranie wdrożyć i to ona wyróżnia irański system na tle innych państw świata. Przy tej okazji warto również nawiązać do popularnego rewolucyjnego sloganu: Nie zachodnia, nie wschodnia, republika islamska! (Na gharbi, na sharghi, ğomhuri-ye eslāmi!). Ta myśl Chomejniego doskonale określiła charakter nowej formy władzy, jako niepodporządkowany ówczesnym siłom zmagającym się ze sobą w zimnowojennej rzeczywistości. Niniejszym Iran w 1979 r. wybrał własną drogę, dystansując się od sojuszów ze Stanami Zjednoczonymi oraz Związkiem Radzieckim.

Ustrój republiki islamskiej w Iranie trwa od czterech dekad w zasadniczo niezmienionej formie ideologicznej i systemowej. Jedynie w 1989 r. pojawiły się poprawki do irańskiej ustawy zasadniczej, które wybór najwyższego przywódcy oddały w ręce Zgromadzenia Ekspertów - Madżles-e Chobregan (Mağles-e Xobregān). W ramach tej procedury wybrany został obecny najwyższy przywódca - Ali Chamenei. Warto przy tej okazji podkreślić, że pierwszego najwyższego przywódcę wybrano w wyborach powszechnych, a zatem bezpośredni wpływ społeczeństwa na funkcjonowanie irańskiego ustroju został w 1989 r. ograniczony.

Sytuacja wokół Iranu pozostaje napięta. Niewątpliwie dzisiejszy niekorzystny i zdemonizowany wizerunek zawdzięcza on po części wyborowi własnej, niezależnej i niepodporządkowanej światowym potęgom drogi egzystowania na arenie międzynarodowej i polityki niepodporządkowania się mocarstwom i obcym ideologicznie wpływom. Pierwszą fazę istnienia IRI - do śmierci Chomejniego w 1989 r. można określić okresem rewolucyjnego populizmu, co zmieniło się później w bardziej pragmatyczne i mniej ideologiczne podejście kolejnych rządów. Jednak ideologia nadal odgrywa istotną rolę w Republice Islamskiej, a Iran pozostaje jednym z najważniejszych orędowników ideologii, którą dziś określa się mianem polityki budowania świata wielobiegunowego. W obecnej sytuacji politycznej oznacza to alians z dążącą do odbudowy swojej mocarstwowej pozycji Rosją i pozostawanie na kursie kolizyjnym z dążącymi do utrzymania statusu jedynego mocarstwa światowego Stanami Zjednoczonymi. Ustrój republiki islamskiej w Iranie jest z tego powodu postrzegany negatywnie szczególnie na Zachodzie, co przejawia się również w próbach określenia go odpowiednim terminem, podejmowanych przez międzynarodowe środowisko naukowe. Demokratyczna teokracja ${ }^{12}$ jest w tym wypadku najłagodniejszym z określeń. Oligarchiczna teokracja, religijna tyrania, po prostu teokracja, czy wreszcie „mułłokracja” to inne terminy, którymi posługuje się środowisko badaczy systemów politycznych ${ }^{13}$.

${ }^{12}$ I. Kurun, Iranian Political System: Mullocracy?, „Journal of Management and Economics Research", Vol. 15, Issue 1, s. 114.

${ }^{13}$ Ibidem, s. 118. 


\section{Powstanie Islamskiej Republiki Afganistanu}

W Afganistanie system republiki islamskiej ma całkowicie odmienną genezę. Został bowiem wprowadzony, pośrednio dzięki interwencji Stanów Zjednoczonych i NATO w $2001 \mathrm{r}$. Afganistan został oficjalnie ogłoszony republiką islamską 7 grudnia 2004 r. po ćwierćwieczu konfliktu zbrojnego (licząc od początku interwencji radzieckiej w 1979 r.). W tym wypadku przyjęcie nowego ustroju nie wpłynęło diametralnie na zmianę wojennej rzeczywistości w kraju, niemniej zakończyło czteroletni okres istnienia teokratycznego systemu wprowadzonego przez mułłę Mohammada Omara (1960-2013) i Ruch Talibów - Islamskiego Emiratu Afganistanu (1996-2001). Mimo wsparcia procesu pokojowego ze strony Stanów Zjednoczonych i ich sojuszników (operacja ISAF $^{14}$ ), sytuacja $\mathrm{w}$ Afganistanie wciąż pozostaje niestabilna i skomplikowana. Działania zbrojne nadal są codzienną rzeczywistością tego państwa, które funkcjonuje w swej obecnej formie w dużej mierze dzięki wsparciu ze strony Stanów Zjednoczonych. Należy dodać, że historia zmian ustrojowych w ostatnich dziesięcioleciach jest w Afganistanie zdecydowanie bogatsza niż w sąsiednim Iranie. Obecna forma ustroju, która zastąpiła wspomniany wyżej, nieuznany przez większość rządów Islamski Emirat Afganistanu, nie jest pierwszą republiką islamską w historii tego państwa. W latach 1992-1996 pogrążony w wojnie domowej Afganistan formalnie funkcjonował już bowiem pod szyldem republiki islamskiej, którą proklamowali w 1992 r. mudżahedini wkrótce po obaleniu rządu Mohammada Nadżibullaha (1947-1996). Wcześniej, w drugiej połowie XX w. Afganistan kilkakrotnie formalnie zmieniał swój ustrój, i tak kolejno od proklamowania monarchii konstytucyjnej w 1964 r., przyjął formę republiki w 1973 r., następnie republiki demokratycznej w 1979 r., by powrócić do republiki (II republika) w $1987 \mathrm{r}^{15}$

Afganistan jest zatem najmłodszą z istniejących republik islamskich, lecz w swym charakterze jest to system i ustrój zdecydowanie odmienny od sąsiedniej Islamskiej Republiki Iranu, nie posiadając zasadniczo komponentu stricte islamskiego zarówno w sensie instytucjonalnym, jak i personalnym, jakim jest

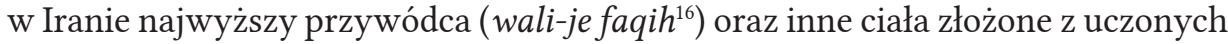
w prawie koranicznym, które funkcjonują w Iranie: Zgromadzenie Ekspertów (Mağles-e Khobregân-e Rahbari) czy Rada Strażników Konstytucji (Shūra-ye Negahbān-e Qānūn-e Asāsī). Tymczasem w przypadku motywów ustanowienia Islamskiej Republiki Afganistanu najczęściej mówi się jedynie o formalnym działaniu politycznym, wynikającym z faktu, że mocno związani regionalnymi

\footnotetext{
${ }^{14}$ Międzynarodowe Siły Wsparcia Bezpieczeństwa, ang. International Security Assistance Force

${ }^{15}$ B.A. Dowlatabadi, Shenasname Afghanistan, Tehran 1381 (2002), s. 292-302.

${ }^{16}$ Przywódca duchowy, najwyższy prawnik muzułmański, określany również terminem rahbar-e enqelab lub w skrócie rahbar.
} (2001-2014) 
więzami sąsiedzi Afganistanu (Iran i Pakistan) to również republiki islamskie ${ }^{17}$, zaś nowy ustrój, wprowadzany niejako pod auspicjami Stanów Zjednoczonych i NATO, miał być zakorzeniony w lokalnych wartościach, z których zdecydowanie najbardziej uniwersalną dla mieszkańców Afganistanu jest islam. Należy przy tym pamiętać, że Afganistan jest państwem multietnicznym i więzy kulturowe oraz językowe były w tym wypadku niewystarczające, by określić mogły jednolicie pojęcie narodu i charakter państwa. Mimo że Afganistan zamieszkują zarówno sunnici, jak i szyici (zarówno imamici, jak i ismailici), jedynym spoiwem w sensie politycznym i społecznym wydaje się dla nich właśnie islam. Problemem Afganistanu pozostają równolegle istniejące odmienne modele kulturowe, a co za tym idzie, modele sprawowania władzy, określane przez Jolantę Sierakowską-Dyndo pozostającymi w konflikcie modelami „struktury koła i struktury piramidy”"

\section{Rola islamu, założenia prawne oraz instytucjonalne IR Iranu i Afganistanu}

Islamska Republika Iranu najczęściej bywa określana mianem teokracji. W rzeczywistości, mając na uwadze poprawność definicji, Iran może być, co najwyżej, uznany za hierokrację, w której władzę nadrzędną sprawuje nie tyle sam Bóg i objawione przez niego prawa, co rahbar - kapłan i najwyższy prawnik muzułmański (obecnie ajatollah Sajjed Ali Chamenei) oraz inne ciała złożone z szyickich duchownych, jak Rada Strażników Konstytucji, mogąca ingerować w możliwości kandydowania poszczególnych obywateli na stanowiska wybierane w toku wyborów powszechnych. W zasadzie jest to jednak system złożony z dwóch komponentów, z tym że komponent islamski (hierokratyczny) należy traktować zdecydowanie jako nadrzędny, względem demokratycznego, mimo spełniania formalnych wymogów trójpodziału władzy, a także obecności takich instytucji, jak wybierany w wyborach powszechnych prezydent i parlament (madżles) oraz wspomniane wyżej Zgromadzenie Ekspertów, które odpowiedzialne jest za wybór najwyższego przywódcy (patrz art. 107 i 111 konstytucji Iranu ${ }^{19}$ ). Nadzór duchowieństwa w osobie najwyższego przywódcy jest kluczową cechą irańskiego systemu, gdyż jego kompetencje zdecydowanie przewyższają wynikające $\mathrm{z}$ prawa wyborczego kompetencje społeczeństwa i wybranych przez nie przedstawicieli. Ponadto rahbar mianuje połowę składu

${ }^{17}$ Zob. M. Rzepka, Hadżḋ i Dżihad. Wptyw islamu na politykę zagraniczna Afganistanu po 2001, [w:] Religia a wspótczesne stosunki międzynarodowe, red. B. Bednarczyk, Z. Pasek, P. Stawiński, Kraków 2010.

${ }^{18}$ Zob. J. Sierakowska-Dyndo, Granice wyobraźni politycznej Afgańczyków. Normatywno-aksjologiczne aspekty tradycji afgańskiej, Warszawa 1998.

${ }^{19}$ Tłumaczenie ustawy zasadniczej IRI na język polski można odnaleźć w: M. Stolarczyk, Iran: państwo i religia, Warszawa 2001, s. 268-318. 
Rady Strażników Rewolucji i w jego gestii znajduje się możliwość odwołania demokratycznie wybranego prezydenta. Owszem, należy przyznać, że najwyższy przywódca sam jest wybierany (i teoretycznie nie dzierży stanowiska dożywotnio) przez demokratycznie wybranych przedstawicieli Rady Ekspertów, jednak w niemal czterdziestoletniej historii republiki islamskiej nie miało jeszcze miejsca zdarzenie, kiedy Zgromadzenie Ekspertów zamierzałoby podważyć kompetencje Chomejniego czy Chameneiego, nie wspominając już o możliwości odwołania rahbara ze sprawowanego urzędu ${ }^{20}$. Najistotniejszą kompetencją rahbara jest, obok wskazania sześciu członków Rady Strażników, wybór szefa władzy sądowniczej, który z kolei wybiera pozostałych sześciu przedstawicieli Rady Strażników.

Ponadto w obecnej sytuacji dominację komponentu religijnego w irańskim systemie politycznym można umocować również, zważając na fakt, że wybrany w wyborach powszechnych w 2013 r. i ponownie cztery lata później prezydent Iranu Hassan Rouhani (ur. 1948), mimo że na tym stanowisku jest to obligatoryjne, jest duchownym szyickim. Wcześniej prezydentem Iranu był świecki Mahmud Ahmadineżad (ur. 1956).

Z kolei w Islamskiej Republice Afganistanu nie istnieje formalnie nadzór duchowieństwa nad działaniem państwa. Wynika to przede wszystkim $\mathrm{z}$ charakteru dominującego wśród obywateli tego państwa islamu sunnickiego (szyici to zaledwie 10-15 proc. afgańskiego społeczeństwa), ale także ze wspomnianej zmiany systemu podyktowanej całkowicie innymi motywami niż w wypadku Iranu, który zmagał się z despotycznym monarchą oraz godzącymi w interesy społeczeństwa wpływami Zachodu. W Afganistanie, paradoksalnie, to właśnie wpływy Zachodu (interwencja w 2001 r., która odsunęła talibów od władzy) z pewnością odegrały istotną rolę świadomościową, co zdecydowało o wyborze tej formy ustrojowej, a właściwie tej nazwy ustroju. Innym czynnikiem, który zauważa m.in. Marcin Rzepka, jest to, że islam w Afganistanie był od początku czynnikiem politycznym, aktywizującym społeczeństwo $\mathrm{w}$ walce $\mathrm{z}$ komunistycznym reżimem i leżał u podstaw ideologii mudżahedinów ${ }^{21}$. Obecny system można potraktować zatem jako syntezę tradycji republikańskich (po przewrocie M. Dauda z 1973 r.) z tradycją mudżahedinów, którzy w imię obrony wiary walczyli z Armią Radziecką w latach 80. XX w. i po obaleniu Nadżibullaha stworzyli pierwszą afgańską republikę islamską. Komponent islamski ma wreszcie za zadanie ukazać islam w korzystnym świetle w kontraście do opresyjnego reżimu talibów (1996-2001), zwanego Islamskim Emiratem Afganistanu i będącego islamską teokracją ${ }^{22}$.

Formalnie afgański system to w swych założeniach z 2004 r. demokratyczny system prezydencki. Prezydent Afganistanu, jak wspomniane zostało

\footnotetext{
${ }^{20}$ I. Kurun, op. cit., s. 119.

${ }^{21}$ M. Rzepka, op. cit.

${ }^{22}$ L. Perl, op. cit., s. 97-112.
} 
w konstytucji; podobnie jak wskazani przez niego wiceprezydenci powinni być muzułmanami ${ }^{23}$. Jest to istotne $\mathrm{w}$ kontekście omawiania islamskiego charakteru współczesnego afgańskiego ustroju, gdyż pozostawia ślad komponentu islamskiego, jednak od prezydenta nie wymaga się formalnie biegłej znajomości prawa koranicznego, czy np. dyplomu ukończenia studiów religijnych, jak ma to miejsce w przypadku wybranych funkcji w Iranie. Co istotne, w wyniku ostatnich wyborów (2014) i kontrowersji, które zapanowały po nich ${ }^{24}$, na mocy porozumienia afgański system został zmodyfikowany, tymczasowo (?) przyjmując także stanowisko szefa władzy wykonawczej ${ }^{25}$ z kompetencjami zbliżonymi do kompetencji premiera w innych państwach. Stojący na czele państwa prezydent jest wybierany na pięcioletnią kadencję w powszechnym głosowaniu (możliwa jest jedna reelekcja) i to on z założenia posiada szerokie uprawnienia wykonawcze (powołuje rząd i dowodzi armią).

Co istotne w kontekście niniejszej analizy, afgański system prawny nie wymaga od osób funkcyjnych biegłej znajomości prawa koranicznego, a na mocy konstytucji z 2004 r. szef afgańskiego sądu najwyższego może mieć świeckie wykształcenie prawnicze lub ukończony fakultet z prawa islamskiego, ale w tym wypadku na zasadzie pełnej dowolności ${ }^{26}$. Władza ustawodawcza z kolei składa się z dwóch izb tzw. Zgromadzenia Narodowego - Szura-je Melli (Šurā-ye Melli), czyli z odpowiednika sejmu - Izby Ludowej - Wolesi Dżirga (Wolesi Ğerga) - 318 członków oraz Rady Starszych - Meszrano Dżirga (Mešrāno Ğerga), która jest odpowiednikiem senatu. Członkowie tych instytucji nie są formalnie zobowiązani do wyznawania religii muzułmańskiej.

Zasadniczo, poza preambułą i pierwszymi trzema artykułami oraz koniecznością wyznawania islamu przez prezydenta, konstytucja Islamskiej Republiki Afganistanu nie definiuje specyficznej roli islamu w życiu politycznym. Niektórzy badacze wskazują jednak pewne sprzeczności w związku z określoną rolą islamu w pierwszych trzech artykułach a kolejnymi. w Art. 1 Afganistan jest określony republiką islamską, niepodległym, jednolitym i niepodzielnym państwem. Na podstawie art. 2 „święta religia islamu” jest religią Islamskiej Republiki Afganistanu. Wyznawcy innych wyznań są wolni w granicach prawa w wykonywaniu swych religijnych obrzędów. Zaś na podstawie art. 3 - żadne prawo nie będzie sprzeczne z zasadami i postanowieniami świętej religii islamu w Afganistanie ${ }^{27}$.

${ }^{23}$ Zob. Rozdz. III Konstytucji Islamskiej Republiki Afganistanu, Prezydent, Art. 62.

${ }^{24}$ J. Gajda, Duet na czele Afganistanu - podsumowanie wyborów i przestroga na przyszłość, „Pulaski Policy Papers”, nr 14, Warszawa 2014, https://pulaski.pl/wp-content/uploads/2015/02/ Komentarz_Miedzynarodowy_Pulaskiego_nr_14_14_PL_2.pdf, dostęp 7.05.2018.

${ }^{25}$ Ang. Chief Executive Officer, dari: ra’is-e e ğrāiya, paszto: de ĕgrāiya ra'is.

${ }^{26}$ Zob. Rozdz. VII Sądownictwo, Art. 118.

${ }^{27}$ Tłum. na podst. The Constitution of Afghanistan, (Ratified) January 26, 2004, http://www. afghanembassy.com.pl/afg/images/pliki/TheConstitution.pdf, dostęp 6.05.2018. 


\section{Republika islamska jako trwała i „elastyczna” forma ustroju politycznego}

W wypadku Iranu, po trzydziestu dziewięciu latach można mówić o trwałości zaadaptowanego w 1979 r. systemu, który zmieniał się w trakcie swego trwania stosunkowo nieznacznie (poprawki do konstytucji w 1989 r.) i pozostały w nim pierwotne założenia sformułowane przez ojca rewolucji islamskiej - Chomejniego. Trwałość irańskiego reżimu, mimo nacisków zewnętrznych i wielu aktorów działających na rzecz upadku islamskiej republiki, świadczy o stabilnych podstawach systemu, ale również stosunkowo dobrym zarządzaniu ze strony wybieranych i niewybieranych władz. W skostniałej formie islamska republika $z$ lat 80 . ubiegłego stulecia mogłaby nie przetrwać długiej próby czasu, dlatego należy uznać ją za ustrój ewoluujący. W ostatnich latach wiele spekuluje się na temat dalszej ewolucji irańskiego ustroju po zbliżającej się niechybnie śmierci ajatollaha Chameneiego ${ }^{28}$.

Turecki badacz Ismail Kurun wskazuje na kilka istotnych zmian, które zaszły w samym systemie oraz elitach irańskiej władzy, które jego zdaniem istotnie wpłynęły na ewolucję Islamskiej Republiki Iranu ${ }^{29}$; po pierwsze irańscy politycy nie podążają już w sposób agresywny za czystością ideologiczną i ekspansją rewolucji islamskiej w polityce zagranicznej, za wyjątkiem zaangażowania w Syrii od początku tzw. Arabskiej Wiosny (co motywowane jest raczej kwestiami strategicznymi wynikającymi z geografii politycznej). Po drugie, najwyższy przywódca w percepcji społecznej nie pełni już funkcji szczególnej, a jest raczej postrzegany jako pierwszy wśród równych, zachodzi przez to stopniowa transformacja od polityki patriarchalnej w kierunku prezydentalizmu. Sam reżim zmienił charakter i odwrócił się od islamskiego totalitaryzmu w kierunku pragmatycznego islamizmu, na co dowodem jest postępująca marginalizacja grup ekstremistycznych na krajowej scenie politycznej. W samych elitach władzy również da się zaobserwować ewolucję światopoglądową od islamskiego uniwersalizmu w kierunku islamizmu narodowego. Niniejszym można dziś zaryzykować twierdzenie, że to już nie jest rewolucja $\mathrm{w} u m m i e^{30}$, lecz irańska islamska rewolucja, której jedynym celem jest utrzymanie w Iranie islamskiej republiki. Jakkolwiek w dobie tzw. Arabskiej Wiosny w irańskich mediach i komentarzach elit politycznych Iranu pojawiały się poglądy, jakoby fala antymonarchistycznych powstań w świecie arabskim była odpowiedzią na irańskie wezwanie do rewolucji islamskiej z 1979 r. Wreszcie obserwuje się deklerykalizację rządu irańskiego, w którym coraz częściej technokraci zastępują rewolucyjnych ideologów. W tym sensie irański system nie jest już

${ }^{28} \mathrm{R}$. Czulda, Iran po nieuchronnej zmianie najwyższego przywódcy, Komentarz Międzynarodowy Pułaskiego, nr 21, Warszawa 2016, http://pulaski.pl/analiza-iran-po-nieuchronnej-zmianie-najwyzszego-przywodcy, dostęp 7.05.2018.

${ }^{29}$ I. Kurun, op. cit., s. $122-123$.

${ }^{30}$ Termin umma używany w znaczeniu religijnym oznacza całą wspólnotę muzułmańską. 
w formie strukturalnej taki sam, jakim stworzony został w wyniku rewolucji. Również najwyższe władze zdają się coraz częściej okazywać przychylność woli ludu i wychodzić naprzeciw oczekiwaniom swych obywateli, kierując się bardziej pragmatyzmem politycznym, aniżeli ideologią.

W Afganistanie z kolei struktura jest młoda i w zasadzie dopiero od $2014 \mathrm{r}$. (zakończenie misji ISAF) samodzielnie funkcjonująca (choć nie w pełni). Trudno zatem oceniać na obecnym etapie jej trwałość i elastyczność. Na uwagę zasługuje jednak casus kryzysu powyborczego w 2014 r., kiedy pojawiły się kontrowersje wokół wyboru na urząd prezydenta Aszrafa Ghaniego, co zakwestionował obóz jego kontrkandydata Abdullaha Abdullaha - kontrowersje są pokłosiem wewnętrznej - afgańskiej pasztuńsko-tadżyckiej rywalizacji w elitach władzy. Istotne jest, że na mocy porozumienia, zasugerowanego przez Stany Zjednoczone, utworzono instytucję szefa władzy wykonawczej, niniejszym zażegnano konfliktu, który mógł nawet doprowadzić do wojny domowej w Afganistanie ${ }^{31}$, która nałożyłaby się niechybnie na wciąż nierozwiązany konflikt pomiędzy siłami rządowymi a Ruchem Talibów oraz innymi grupami zbrojnymi, uznawanymi przez społeczność międzynarodową za terrorystyczne.

\section{Podsumowanie: wpływ kultury politycznej na ustrój islamskiej republiki w Afganistanie i Iranie}

Wspomniane systemy choć dzierżące wspólną nazwę republiki islamskiej są w praktyce całkowicie różne od siebie. Republika islamska jako forma ustroju to pojęcie niezwykle pojemne i jednocześnie nieprecyzyjne w kontekście próby zdefiniowania i opisania tej formy ustroju. Na obecny kształt systemów politycznych w Afganistanie oraz Iranie duży wpływ wywarła niewątpliwie kultura polityczna i środowisko, w którym ustroje tych państw powstawały, a obecnie wciąż się kształtują. W obu przypadkach nastąpiła adaptacja właściwych dla danego państwa praw, wartości i tradycji do systemu funkcjonowania państwa. W Afganistanie, w którym ogromną rolę odgrywa tożsamość etniczna i plemienna, istnieje specyficzna instytucja zwana Wielką Radą, z języka paszto - Loja Dżirga (Loya Ğerga). Wielka Rada jest tradycyjnym pasztuńskim zgromadzeniem przedstawicieli wszystkich plemion i klanów, które niezależnie od działań stałych organów i instytucji zwoływane jest w wyjątkowych sytuacjach i zajmuje się działaniem w najistotniejszych sprawach wagi państwowej (śmierć prezydenta, przyjęcie nowej konstytucji, wojna etc.). Przeniesiona na grunt systemowy Loja Dżirga to najwyższy organ, w którego skład wchodzą wszyscy delegaci starszyzny plemiennej, reprezentujący wszystkie plemiona i regiony Afganistanu.

${ }^{31}$ T. Clayton, K. Katzman, Afghanistan: Post-Taliban Governance, Security and U.S. Policy, CRS Report, 13.12.2017, s. 8-9, https://fas.org/sgp/crs/row/RL30588.pdf, dostęp 7.05.2018. 
Iran uznać należy z kolei za najbardziej wyrazistą spośród republik islamskich. To państwo w którym rzeczywiście rządy sprawuje szyicki kler, choć nie można odmówić mu cech demokratycznych. Specyfika systemu wynika w tym wypadku z długiej historii kształtowania się kultury politycznej. Iran jako największe państwo szyickie posiada wielowiekowe tradycje państwowości sięgające jeszcze imperium Achemenidów. Wyraźnego odwołania do władania państwem dzięki „Bożej łasce” można dopatrywać się w irańskiej tradycji zoroastryjskiej imperiów Achemenidów (550-330 p.n.e.) czy szczególnie Sasanidów (224-651), którzy uznali zoroastryzm za religię państwową ${ }^{32}$. Również wielowiekowe tradycje wymiany kulturowej zapoczątkowane w dobie podbojów achemenidzkich, a następnie piętno odciśnięte przez Aleksandra Macedońskiego i kulturę helleńską pozostawiły trwały ślad na koncepcjach kształtujących republikę islamską w Iranie. Wreszcie najważniejszym elementem jest przyniesiony przez Arabów islam, który w formie szyickiej w Persji został w 1501 r. uznany za religię państwową. To szyizm w Iranie wykształcił kulturę polityczną, która oparła się fali kolonializmu w regionie w XIX i na początku $\mathrm{XX}$ w. Iran jako pierwsze państwo w regionie Bliskiego Wschodu przyjął konstytucję (1907), która zakładała trójpodział władzy. Szach miał wówczas stanowić organ władzy wykonawczej i stać na czele monarchii konstytucyjnej. Jednak de facto konstytucja irańska pozostawała martwa. To właśnie doprowadziło do odnowy ruchu szyickiego w Iranie i wreszcie ukształtowania koncepcji republiki islamskiej ajatollaha Chomejniego. System w Iranie niewątpliwie przeszedł drogę od rewolucyjnego populizmu do pragmatyzmu skierowanego na rozwój gospodarczy i budowę regionalnej potęgi.

Reasumując, w obu państwach obowiązuje islamski system polityczny o tyle, że stosunki polityczne wedle założeń mają być zgodne z zasadami religijnymi islamu oraz bazować na wartościach zawartych w Koranie. Poza tym afgański system prezydencki jest całkowicie różny od systemu obowiązującego w Iranie. Islamska republika jako ustrój państwa nie determinuje zatem charakteru państwa i panującej w nim rzeczywistości politycznej.

${ }^{32}$ Zob. L. Perl, op. cit., s. 16-17. 